\title{
Endogenous ABA content in relation to maturation of somatic embryos in Tulipa (L.) 'Apeldoorn' cultures
}

\author{
Małgorzata Maślanka ${ }^{1}$ Anna Bach ${ }^{1}$ - Franciszek Janowiak ${ }^{2}$
}

Received: 28 April 2016/Revised: 6 July 2016/ Accepted: 22 October 2016/Published online: 2 November 2016 (C) The Author(s) 2016. This article is published with open access at Springerlink.com

\begin{abstract}
The aim of the present study was to estimate the endogenous abscisic acid (ABA) content in tulip 'Apeldoorn' torpedo and mature somatic embryos. Moreover, the effect of exogenous ABA and/or its inhibitor fluridone on somatic embryo maturation and conversion into plantlets was investigated. Torpedo-stage somatic embryos were subcultured on media containing $5 \mu \mathrm{M}$ of picloram and $1 \mu \mathrm{M}$ of 6-benzyl-aminopurine (BAP)—control, and combinations of $\mathrm{ABA}(0$ or $10 \mu \mathrm{M})$ and/or fluridone $(0$ or $30 \mu \mathrm{M})$ for 1 week. Then, the torpedo embryos were transferred to a maturation medium containing $0.25 \mu \mathrm{M}$ of $\alpha$-naphthaleneacetic acid (NAA) and $2.5 \mu \mathrm{M}$ of BAP, without $\mathrm{ABA}$ and fluridone treatment, and cultivated under darkness or light for ten weeks. Endogenous ABA content (first time measured in tulip somatic embryos) was evaluated by ELISA test. The obtained results revealed that the highest level of endogenous ABA, at $17.45 \mathrm{nmol} \mathrm{g}^{-1}$ dry weight (DW), was recorded in torpedo-stage of tulip embryo development, only after 1 week of ABA treatment, and was nearly 10 times higher in comparison with the control. Simultaneous addition of ABA and fluridone to the medium resulted in the lowering of the ABA concentration to $9.58 \mathrm{nmol} \mathrm{g}{ }^{-1}$ DW. During ten weeks of maturation of the embryos, the endogenous ABA content in mature tissue of tulip somatic embryo considerably decreased to an amount
\end{abstract}

Communicated by $\mathbf{J}$ van Huylenbroeck.

Małgorzata Maślanka

m.maslanka@ogr.ur.krakow.pl

1 Department of Ornamental Plants, University of Agriculture in Kraków, Al. 29 Listopada 54, 31-425 Kraków, Poland

2 Department of Ecophysiology, Institute of Plant Physiology, Polish Academy of Sciences, Niezapominajek 21, 30-239 Kraków, Poland
0.87-1.33 $\mathrm{nmol} \mathrm{g}^{-1} \mathrm{DW}$ (irrespective of ABA and fluridone treatment) and did not differ significantly from control $\left(0.59 \mathrm{nmol} \mathrm{g}^{-1} \mathrm{DW}\right)$. Exogenous ABA and fluridone significantly decreased the growth value of fresh weight $(\mathrm{FW})$ of the tulip torpedo-shaped and mature embryos under light conditions. Percentage of the DW of the torpedo embryos treated with exogenous $\mathrm{ABA}$ was significantly higher (15.43-17.02) in comparison with the control (10.87). Three to three and a half times more malformed mature embryos were noted under light conditions than in darkness, irrespective of ABA and fluridone treatment. The highest percentage of mature embryos forming shoots (conversion) was observed under light conditions in the control and after fluridone treatment (26 and $20 \%$, respectively).

Keywords Tulipa Somatic embryo maturation - ABA . Fluridone

\section{Introduction}

The traditional, vegetative way of new tulip cultivars propagation is very time consuming (Eijk et al. 1991; Rees 1992; De Hertogh and Le Nard 1993; Custers et al. 1997). It is possible to shorten the process using in vitro culture techniques. The most effective method seems to be somatic embryogenesis (SE) (Gude and Dijkema 1997), which enables large-scale propagation of many geophytes (Stefaniak 1994; Nhut et al. 2006; Bakhshaie et al. 2010; Gao et al. 2010; Subotić et al. 2010). Somatic embryogenesis also makes it possible to investigate factors involved in the process (Find 1997; Senger et al. 2001) and to study the physiological, biological, and molecular events occurring during embryo development (Zimmerman 1993; Ogata et al. 2005; Quiroz-Figueroa et al. 2006). 
To induce somatic organogenesis, the culture medium is supplemented mainly with an auxin, which determines the initiation of somatic embryos (Zimmerman 1993; Dodeman et al. 1997; Gude and Dijkema 1997; Raghavan 1997, Bach and Ptak 2001). The auxin most frequently used in tulip SE is picloram (Gude and Dijkema 1997; Ptak and Bach 2007). Apart from auxin, bulbous plants for SE initiation also require a cytokinin, e.g. BAP (Malik 2008; Maślanka and Bach 2010). Initiated somatic embryos can develop into whole plants under appropriate conditions (Ogata et al. 2005). For proper maturation and conversion, somatic embryos must first achieve morphological maturity and then-by undergoing a desiccation period-physiological maturity (Stasolla and Yeung 2003). For this purpose, they are subcultured on maturation media containing lower levels of growth regulators, or on a hormone-free MS (Murashige and Skoog 1962) medium (Gude and Dijkema 1997; Raghavan 1997; Bakhshaie et al. 2010).

In spite of numerous studies in various genera, somatic embryogenesis is still presenting difficulties such as low number of generated embryos and low frequency of mature embryos converting into plantlets (Stasolla and Yeung 2003; Kępczyńska and Zielińska 2006). The problems occur due to largely unknown biochemical and molecular mechanisms involved in SE (Quiroz-Figueroa et al. 2006). It is well known that somatic embryo quality determines the efficiency of somatic embryogenesis. Poor quality of somatic embryos is very often caused by low levels of storage reserves (Madakadze and Senaratna 2000), which results from a different synthesis pathway in comparison with seeds (Schmidt et al. 2005). The accumulation of storage proteins, starch, and lipids in plants-also during embryogenesis and germination of zygotic embryos-is affected by abscisic acid (ABA) (Seo and Koshiba 2002). ABA is involved in many physiological responses, such as alterations in nucleotide biosynthesis (Ashihara et al. 2001), alterations in nitrogen (Sreedhar and Bewley 1998), carbon (Goupil et al. 1998) and ascorbic acid metabolisms (Stasolla and Yeung 2003), and in the synthesis of polyamines (Minocha et al. 1999).

Protocols currently developed for tulip SE also yield low-quality somatic embryos, with insufficient conversion into plants (Ptak and Bach 2007; Maślanka and Bach 2010). To exploit the favourable effect of ABA during SE in certain plants (Li and Wolyn 1996; Vágner et al. 1998; Yoshioka et al. 1998; Stasolla and Yeung 2003; GarciaMartin et al. 2005), we decided for the first time to examine its impact on quality (biometrical features) of tulip somatic embryos. To that end, the tulip somatic embryo media were supplemented with ABA, alone or together with fluridone-an ABA biosynthesis inhibitor.

In our study, for the first time, there has been also examined endogenous ABA content in tulip torpedo and mature somatic embryos tissue in relation to exogenous $\mathrm{ABA}$ and fluridone treatment.

\section{Materials and methods}

\section{Plant material}

The studies were conducted on the Tulipa 'Apeldoorn' torpedo somatic embryos. Induction of somatic embryogenesis and differentiation of somatic embryos were carried out following the procedure developed in Department of Ornamental Plants in Kraków by Bach and Ptak (2001).

Embryogenic callus, obtained from ovary explants after 16-20 weeks of culture, was put on an MS medium with $5 \mu \mathrm{M}$ of picloram, $1 \mu \mathrm{M}$ of BAP, and $3 \%$ of sucrose in order to produce torpedo somatic embryos.

\section{Somatic embryos maturation and conversion: ABA/ fluridone treatment}

Torpedo-stage somatic embryos, formed after 12 weeks of embryogenic callus culture, 5-10 mm in length (Fig. 1a), were subcultured on control media (containing $5 \mu \mathrm{M}$ of picloram, $1 \mu \mathrm{M}$ of $\mathrm{BAP}, 0 \mu \mathrm{M}$ of $\mathrm{ABA}$, and $0 \mu \mathrm{M}$ of fluridone) and media supplemented with (despite of picloram and BAP content) combinations of $\mathrm{ABA}$ and fluridone (10 $\mu \mathrm{M}$ ABA, $10 \mu \mathrm{M}$ ABA and $30 \mu \mathrm{M}$ fluridone, $30 \mu \mathrm{M}$ fluridone) for 1 week. The concentration of ABA and duration of its treatment were established according to previous results (Maślanka and Bach 2005). Then, the embryos were transferred to a maturation medium containing $0.25 \mu \mathrm{M}$ of NAA and $2.5 \mu \mathrm{M}$ of BAP, and cultivated in darkness or under $16 \mathrm{~h}$ white light (fluorescent lamps, PPFD $30 \mu \mathrm{mol} \mathrm{m} \mathrm{s}^{-2}$ ) at $25 \pm 2{ }^{\circ} \mathrm{C}$ for 10 weeks.

\section{Biometrical observations}

The torpedo somatic embryos, after 1 week of ABA/fluridone treatment, were measured in respect of the $\mathrm{FW}$, the embryo's length, and DW. The change in FW was estimated using the growth value indicator $(\mathrm{GV}) . \mathrm{GV}=$ $\left(\mathrm{FW}_{\text {final }}-\mathrm{FW}_{\text {initial }}\right) / \mathrm{FW}_{\text {initial }}$ (Ziv 2005). DW of the somatic embryos was determined after drying in an evaporator at $60{ }^{\circ} \mathrm{C}$ for $72 \mathrm{~h}$. After the next 10 weeks, observations of post-treatment effect of $\mathrm{ABA}$ and fluridone were completed on the percentage of malformed, viable, and shoot-forming converted embryos (from viable mature embryos). Malformed embryos had developed twisted or curled cotyledons. Dead embryos turned brown with no sign of growth. Maturation was defined as further increase in $\mathrm{GV}$ of fresh weight of the embryos and increase in 


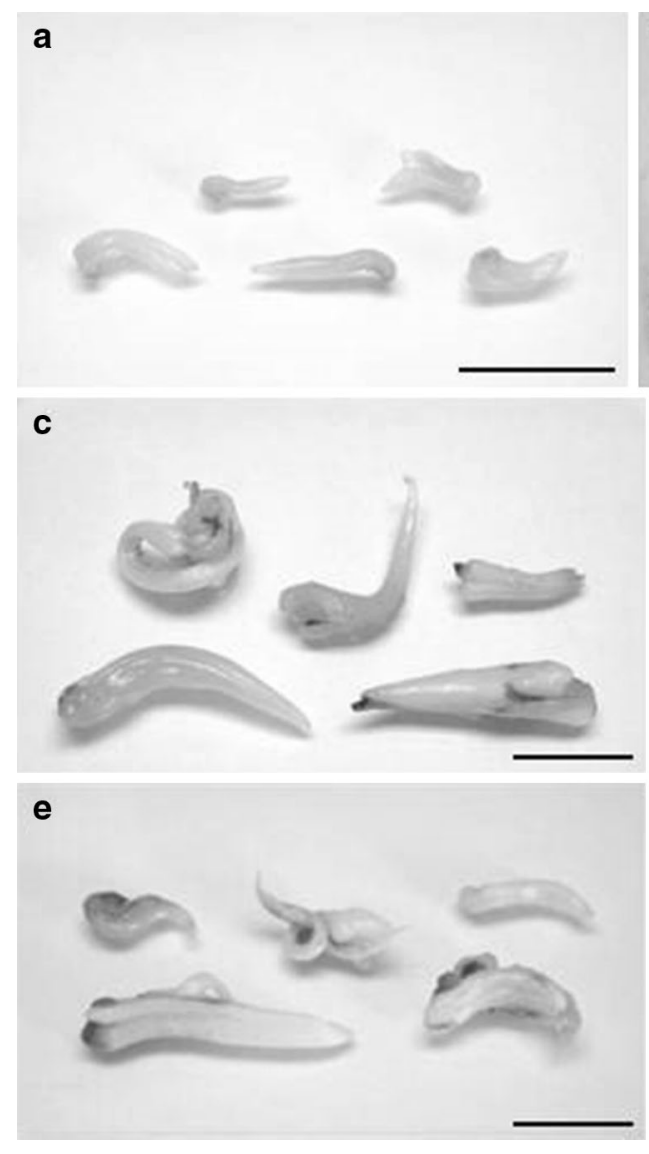

Fig. 1 Tulip somatic embryos before ABA treatment (a). Tulip somatic embryo conversion into plantlet-see an arrow (b). Control somatic embryos, without $\mathrm{ABA}$ treatment, in darkness (c) and light

length of their cotyledons. Conversion was defined as forming of shoots by the mature embryos.

Total number of somatic embryos used for biometrical analyses was 100 .

\section{Determination of ABA content}

Endogenous $\mathrm{ABA}$ content in tulip somatic embryos was determined after 1 week of $\mathrm{ABA} /$ fluridone treatment and after 10 weeks of maturation of the embryos. After the freeze-drying process (LABCONCO, Kansas City, MO, USA), the plant material (tulip torpedo or mature somatic embryos, cultivated in the dark) was ground in a ball mill MM400 (Retch, Kroll, Germany) to which cold distilled water was then added. The samples were heated for $3 \mathrm{~min}$ in boiling water and then shaken overnight at $4{ }^{\circ} \mathrm{C}$. On the following day, the extracts were centrifuged for $20 \mathrm{~min}$ in a cool centrifuge at 18,000 $\mathrm{g}$ (MPW-350R, Poland). The ABA content in the supernatant was determined by the indirect enzyme-linked immunosorbent assay (ELISA) according to the protocol of Walker-Simmons and Abrams (1991) using ABA-specific antibodies MAC 252 (Babraham Bioscience Technologies, Cambridge, UK). Absorbance was measured
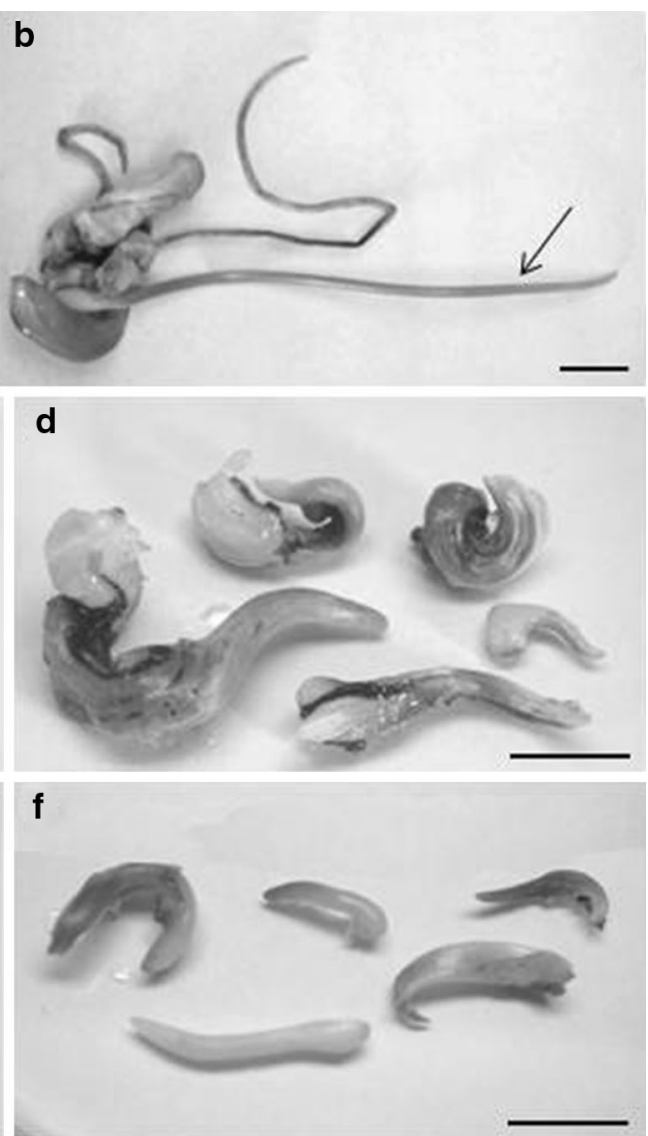

(d). Somatic embryos 10 weeks after ABA treatment, in darkness (e) and light (f). Bars $1 \mathrm{~cm}$

by microplate reader Model 680 (Bio-Rad Laboratories, Inc., USA) at the wavelength of $405 \mathrm{~nm}$.

\section{Statistical analysis}

The experiment of $\mathrm{ABA} /$ fluridone treatment, embryo maturation, and conversion were performed in five replications with five explants each. In case of determination of ABA content, for each treatment, 3 independent ELISA measurements with 3 replicates for 2 samples of plant material were performed. The results were analysed using the method of analysis of variance into which the percentages have been transformed (Bliss 1938). Comparison of mean values was made with Duncan's test at a significance level of $P \leq 0.05$ using STATISTICA 9.0 (Stat-Soft, Inc., USA) software package.

\section{Results}

In the experiment, the $\mathrm{ABA}$ and fluridone treatment affected biometrical features of embryos. The obtained results revealed that $\mathrm{ABA}$ and fluridone treatment 
Table 1 Effect of ABA/fluridone on the features of tulip torpedo somatic embryos after 1 week of culture in darkness

\begin{tabular}{|c|c|c|c|c|}
\hline $\begin{array}{l}\text { Growth regulators } \\
\text { in medium }(\mu \mathrm{M})\end{array}$ & $\begin{array}{l}\text { ABA/fluridone treatment } \\
(\mu \mathrm{M})\end{array}$ & $\begin{array}{l}\text { Growth value of } \\
\text { fresh weight }(\mathrm{GV})\end{array}$ & $\begin{array}{l}\text { Increase in embryo } \\
\text { length }(\mathrm{mm})\end{array}$ & $\begin{array}{l}\text { Dry weight } \\
\text { (DW) }(\%)\end{array}$ \\
\hline \multirow[t]{4}{*}{5 picloram, $1 \mathrm{BAP}$} & $0 \mathrm{ABA}, 0$ fluridone (control) & $0.47 \mathrm{a}^{\mathrm{a}}$ & $0.48 \mathrm{a}$ & $10.87 b$ \\
\hline & $10 \mathrm{ABA}$ & $0.12 b$ & $0.68 \mathrm{a}$ & $17.02 \mathrm{a}$ \\
\hline & $10 \mathrm{ABA}, 30$ fluridone & $0.09 b$ & $0.56 \mathrm{a}$ & $15.43 \mathrm{a}$ \\
\hline & 30 fluridone & $0.1 \mathrm{~b}$ & $0.88 \mathrm{a}$ & $11.23 b$ \\
\hline
\end{tabular}

${ }^{a}$ Mean values followed by the same letters in columns do not differ according to Duncan's test at the significance level of $P \leq 0.05$

significantly decreased the growth value of FW in tulip torpedo somatic embryos during the 1-week culture period. The dry weight of the embryos treated with ABA (alone, or together with fluridone) was about 1.5-fold higher in comparison with the control, and constituted a significant difference. The increase in length of all the embryos was in the range of $0.56-0.88 \mathrm{~mm}$ and did not differ in comparison with control (Table 1).

The following results were recorded with regard to the post-treatment effect of the growth regulators and lighting conditions on maturation of the tulip embryos. The highest increase in the GV of mature embryos, amounted 16.16, was observed in the control, under light (Table 2). In darkness, the GV (ranging from 2.89 to 4.14) did not differ significantly between ABA/fluridone treatments. Light enhanced the mass of all the mature somatic embryos due to higher absorption of water, as indicated by DW. ABA treatment in darkness significantly decreased the GV of the embryos in comparison with light. Darkness had a positive influence on mature embryo DW, especially after previous application of ABA. The length of all the embryos was favourably affected by light (Fig. 1c-f), although significant differences between the means were noted only in the case of tulip mature embryos treated with ABA and fluridone (Table 2).

An increase in the length of the mature embryos was accompanied by an increase in their malformations (Table 3) (Fig. 1c-f). Considerable differences between the effects of light and darkness on number of malformed embryos were observed in ABA/fluridone-treated embryos. In those cases, 3-3.5 times more malformed embryos were noted under light conditions than in darkness (Table 3).

The mature somatic embryos were green (data not shown) and viable. Only the embryos treated with fluridone and light adversely affected embryo viability, which amounted to $72 \%$ (Table 3).

Conversion of 'Apeldoorn' somatic embryos consists of the development of shoots only. In our study we have not observed development of any roots (Fig. 1b). The highest percentage of mature embryos forming shoots was

Table 2 Post-effect of ABA/fluridone on the features of mature tulip somatic embryos after 10 weeks of culture

\begin{tabular}{|c|c|c|c|c|c|}
\hline $\begin{array}{l}\text { Growth regulators in maturation } \\
\text { medium }(\mu \mathrm{M})\end{array}$ & $\begin{array}{l}\text { Previous treatment of } \mathrm{ABA} / \\
\text { fluridone }(\mu \mathrm{M})\end{array}$ & $\begin{array}{l}\text { Light } \\
\text { conditions }\end{array}$ & $\begin{array}{l}\text { Growth value of fresh } \\
\text { weight }(\mathrm{GV})\end{array}$ & $\begin{array}{l}\text { Increase in } \\
\text { length }(\mathrm{mm})\end{array}$ & $\begin{array}{l}\text { Dry weight } \\
(\mathrm{DW})(\%)\end{array}$ \\
\hline \multirow[t]{11}{*}{$2.5 \mathrm{BAP}, 0.25 \mathrm{NAA}$} & \multirow[t]{2}{*}{0 ABA, 0 fluridone (control) } & Darkness & $4.04 c^{1}$ & 8.96abc & $18.63 \mathrm{abc}$ \\
\hline & & Light & $16.16 \mathrm{a}$ & $15.76 a$ & $16.07 \mathrm{bcd}$ \\
\hline & \multirow[t]{2}{*}{10 ABA } & Darkness & $3.49 \mathrm{c}$ & $5.44 \mathrm{c}$ & $19.54 \mathrm{ab}$ \\
\hline & & Light & $9.8 b$ & $11.94 \mathrm{abc}$ & $11.9 \mathrm{de}$ \\
\hline & \multirow[t]{2}{*}{10 ABA, 30 fluridone } & Darkness & $2.89 \mathrm{c}$ & $6.32 \mathrm{c}$ & $21.47 \mathrm{a}$ \\
\hline & & Light & $10.45 b$ & $13.74 \mathrm{ab}$ & $10.57 \mathrm{e}$ \\
\hline & \multirow[t]{2}{*}{30 fluridone } & Darkness & $4.14 \mathrm{c}$ & $7.44 \mathrm{bc}$ & $17.82 \mathrm{abc}$ \\
\hline & & Light & $6.62 \mathrm{bc}$ & $10.62 \mathrm{abc}$ & $14.12 \mathrm{cde}$ \\
\hline & Treatment & & $*$ & NS & NS \\
\hline & Light conditions & & $* * *$ & $* * *$ & $* * *$ \\
\hline & Treatment $\times$ light conditions & & $*$ & NS & NS \\
\hline
\end{tabular}

The results of factorial ANOVA are presented in the lower part of the table. The sources of variance for separate features were as follows: four treatments, two light conditions and interaction between treatment and light conditions

$N S$ not significant

*, **, ***, Significant at $P<0.05,0.01,0.001$, respectively

${ }^{1}$ For explanations see Table 1 
Table 3 Post-effect of ABA/fluridone on the maturation and conversion (forming of shoots) of tulip somatic embryos after 10 weeks of culture

\begin{tabular}{|c|c|c|c|c|c|}
\hline $\begin{array}{l}\text { Growth regulators in maturation } \\
\text { medium }(\mu \mathrm{M})\end{array}$ & $\begin{array}{l}\text { Previous treatment of } \mathrm{ABA} / \\
\text { fluridone }(\mu \mathrm{M})\end{array}$ & $\begin{array}{l}\text { Light } \\
\text { conditions }\end{array}$ & $\begin{array}{l}\text { Malformations } \\
(\%)\end{array}$ & $\begin{array}{l}\text { Viability } \\
(\%)\end{array}$ & $\begin{array}{l}\text { Forming of shoots } \\
(\%)\end{array}$ \\
\hline \multirow[t]{11}{*}{2.5 BAP, 0.25 NAA } & \multirow[t]{2}{*}{0 ABA, 0 fluridone (control) } & Darkness & $40 a b c d^{1}$ & $100 \mathrm{a}$ & $2.4 \mathrm{c}$ \\
\hline & & Light & $60 \mathrm{ab}$ & $100 \mathrm{a}$ & $26 a$ \\
\hline & \multirow[t]{2}{*}{10 ABA } & Darkness & $20 \mathrm{~cd}$ & $100 \mathrm{a}$ & $12 \mathrm{bc}$ \\
\hline & & Light & $68 \mathrm{a}$ & $92 \mathrm{a}$ & $6.4 \mathrm{c}$ \\
\hline & \multirow[t]{2}{*}{10 ABA, 30 fluridone } & Darkness & $16 \mathrm{~d}$ & $100 \mathrm{a}$ & $6 c$ \\
\hline & & Light & $48 \mathrm{abc}$ & $92 \mathrm{a}$ & $4 \mathrm{c}$ \\
\hline & \multirow[t]{2}{*}{30 fluridone } & Darkness & 44abcd & $100 \mathrm{a}$ & $4 c$ \\
\hline & & Light & 36bcd & $72 b$ & $20 \mathrm{ab}$ \\
\hline & Treatment & & NS & $*$ & NS \\
\hline & Light conditions & & $* *$ & $* *$ & $* *$ \\
\hline & Treatment $\times$ light conditions & & $*$ & $*$ & $* * *$ \\
\hline
\end{tabular}

${ }^{1} \mathrm{NS}, *, * *, * * *$ For explanations see Table 2

observed under light, in the control and after fluridone treatment (26 and 20\%, respectively). What is more, only in those cases did the light favourably influence shoot development. In other cases, there were no significant differences between the light and darkness in forming shoots by the embryos (Table 3 ).

The torpedo-stage and mature embryos, cultivated in the dark, were examined in respect of the endogenous $\mathrm{ABA}$ content, both after the application of exogenous ABA and fluridone and after their removal from the medium. The analyses revealed that the highest level of $\mathrm{ABA}$, at $17.45 \mathrm{nmol} \mathrm{g}{ }^{-1} \mathrm{DW}$, was recorded after one week of ABA treatment of torpedo embryos and was nearly ten times higher in comparison with control $\left(1.82 \mathrm{nmol} \mathrm{g}^{-1} \mathrm{DW}\right)$. Simultaneous addition of ABA and fluridone to the medium resulted in the lowering of the ABA concentration to $9.58 \mathrm{nmol} \mathrm{g}^{-1}$ DW (Table 4).

After 10-week period of maturation of embryos, the endogenous ABA content considerably decreased to an amount approximately $1 \mathrm{nmol} \mathrm{g}^{-1} \mathrm{DW}$. Only under the influence of fluridone did the ABA concentration remain at a similar level $\left(0.98-1.33 \mathrm{nmol} \mathrm{g}^{-1} \mathrm{DW}\right)$, irrespective of the stage of embryo development and the presence of fluridon—an ABA biosynthesis inhibitor (Table 4).

\section{Discussion}

Somatic embryogenesis plays a significant role in plant propagation and has very important biotechnological applications such as artificial seeds, micropropagation and transgenic plants (Quiroz-Figueroa et al. 2006; Bakhshaie et al. 2010). The major factors affecting the maturation and conversion of somatic embryos are media additives like
Table 4 Effect of ABA/fluridone on the endogenous ABA content in tulip somatic embryos

\begin{tabular}{|c|c|c|c|}
\hline $\begin{array}{l}\text { One week treatment } \\
\text { of } \mathrm{ABA} / \text { fluridone } \\
(\mu \mathrm{M})\end{array}$ & $\begin{array}{l}\text { Duration of } \\
\text { cultivation } \\
\text { (weeks) }\end{array}$ & $\begin{array}{l}\text { Stage of } \\
\text { embryo } \\
\text { development }\end{array}$ & $\begin{array}{l}\text { ABA content } \\
\left(\mathrm{nmol} \mathrm{g}^{-1} \mathrm{DW}\right)\end{array}$ \\
\hline \multirow{2}{*}{$\begin{array}{l}0 \text { ABA, } 0 \text { fluridone } \\
\text { (control) }\end{array}$} & 1 & Torpedo & $1.82 c^{2}$ \\
\hline & 10 & Mature & $0.59 \mathrm{~d}$ \\
\hline \multirow[t]{2}{*}{$10 \mathrm{ABA}$} & 1 & Torpedo & $17.45 \mathrm{a}$ \\
\hline & 10 & Mature & $1.04 \mathrm{~cd}$ \\
\hline \multirow[t]{2}{*}{10 ABA, 30 fluridone } & 1 & Torpedo & $9.58 b$ \\
\hline & 10 & Mature & $0.87 \mathrm{~cd}$ \\
\hline \multirow[t]{2}{*}{30 fluridone } & 1 & Torpedo & $0.98 \mathrm{~cd}$ \\
\hline & 10 & Mature & $1.33 \mathrm{~cd}$ \\
\hline \multicolumn{3}{|l|}{ Treatment } & $* * *$ \\
\hline \multicolumn{3}{|c|}{ Stage of embryo development } & $* * *$ \\
\hline \multicolumn{3}{|c|}{$\begin{array}{l}\text { Treatment } \times \text { stage of embryo } \\
\text { development }\end{array}$} & $* * *$ \\
\hline
\end{tabular}

$N S$ not significant

$*, * *, * * *$, Significant at $p<0.05,0.01,0.001$, respectively

${ }^{1}$ Maturation medium contains $0.25 \mu \mathrm{M}$ NAA and $2.5 \mu \mathrm{M}$ BAP

${ }^{2}$ Mean values followed by the same letters do not differ according to Duncan's test at the significance level of $P \leq 0.05$. The results of factorial ANOVA are presented in the lower part of the table. The sources of variance for separate features were as follows: four treatments, two stages of embryo development and interaction between treatment and stages of embryo development

nutritional and growth regulatory substances (Madakadze and Senaratna 2000), different from those inducing embryogenesis (Raghavan 1997).

In the present study, the maturation and conversion of tulip somatic embryos were examined on media containing, apart from auxins and cytokinins, other growth regulators: 
ABA and fluridone. By controlling gene expression connected with the vegetative development of plants (Seo and Koshiba 2002), ABA stimulates somatic embryo development and quality, which has been observed in many plants, e.g. Asparagus officinalis (Li and Wolyn 1996), Quercus suber (Garcia-Martin et al. 2005), Quercus ilex (Mauri and Manzanera 2004), Picea abies (Vágner et al. 1998), Hevea brasiliensis (Linossier et al. 1997). Fluridone was applied to unambiguously verify the influence of ABA (Gamble and Mullet 1986, Kępczyńska and Zielińska 2006).

Considering the influence of ABA on the biometrical features of torpedo and mature tulip embryos, the torpedo embryos showed a significantly lower growth value of FW after the addition of $10 \mu \mathrm{M}$ of exogenous ABA. Similar results were also observed after the removal of the ABA (maturation of embryos), in light only. Senger and coworkers (2001) made opposite observations with somatic embryos of Nicotiana plumbaginifolia, as all the investigated lines showed steady increase in fresh weight. On the other hand, the DW of tulip somatic torpedo embryos treated with ABA was considerably higher in comparison with the control. Such results suggest that the ABA-treated embryos absorbed less water from the medium or that ABA enhanced the accumulation of storage materials (Kępczyńska and Zielińska 2006). Higher DW in ABA-treated somatic embryos and higher water content in the embryos cultured on a medium without ABA were also observed in Quercus ilex (Mauri and Manzanera 2004). One week of treatment with $10 \mu \mathrm{M}$ of ABA enhanced the maturation percentage of Quercus suber somatic embryos and increased their fresh and dry matter contents (GarciaMartin et al. 2005). The same ABA concentration $(10 \mu \mathrm{M})$ resulted in a superior quality of Picea abies somatic embryos (Vágner et al. 1998). Exogenous ABA is necessary for appropriate growth not only of conifer somatic embryos (Stasolla and Yeung 2003 Find 1997), but also Asparagus officinalis (Li and Wolyn 1996), Daucus carota (Hatzopoulos et al. 1990), and Pelargonium $\times$ hortorum (Madakadze and Senaratna 2000). It is very important to apply ABA at an appropriate embryo developmental stage and proper dose, because the hormone can inhibits embryo growth (Tettero et al. 1995, Raghavan 1997). In our previous study, when tulip somatic embryos had been treated with higher concentration of ABA $(19 \mu \mathrm{M})$ for 2 or 4 weeks, the embryos reached a dormancy (Maślanka and Bach 2005).

In our present study, we observed a positive post-treatment influence of ABA on lowering the level of malformed tulip embryos, but cultured only in darkness. Activity of ABA is correlated with environmental lighting conditions of culture (Weatherwax et al. 1996) and its endogenous content in plant tissues is lower in light (Reynolds and Crawford 1997; Kraepiel and Miginiac 1997). Probably, under light conditions, endogenous ABA content in tulip 'Apeldoorn' decreased and the embryos, which were formed in light, were more malformed in comparison with embryos grown in darkness. Considering embryos conversion, (forming of shoots) it was stated that light enhanced this process only in case of embryos non-treated with ABA. Significant shoots formation in such conditions may be explained by lower ABA content in plants cultivated under light conditions and lower inhibitory effect of ABA (Reynolds and Crawford 1997, Kraepiel and Miginiac 1997). Light conditions_-spectrum of light—play an important role in conversion of somatic embryos in cultures of tulip (Bach and Pawłowska 2006). Light enhanced the increase in growth value of fresh weight and length, which means that tulip somatic embryos developed faster in light. Unfortunately, the quicker development was connected with a higher percentage of deformations and lower DW accumulation, in comparison with darkness. Darkness seemed to have a more favourable impact on embryo development, if not on lowering the ability of shoot formation. In the experiment with Medicago truncatula (Nolan and Rose 1998), darkness improved embryo quality, whereas the presence of light markedly inhibited the efficiency of embryo conversion. According to Garcia and co-workers (2007), light can modulate the action of different growth regulators inducing various morphogenic responses. ABA has been found to adversely affect shoot regeneration in Cocos nucifera (Perera et al. 2009). This hormone also inhibited regeneration of Medicago sativa somatic embryos (Kępczyńska and Zielińska 2006). In the case of Picea glauca (Attree et al. 1991), ABA had a negative impact on the germination of somatic embryos.

Considering the influence of fluridone on maturation and conversion of tulip embryos, it was stated that after the treatment with $30 \mu \mathrm{M}$ of fluridone, the tulip somatic embryos had significantly lower DW than after simultaneous application of fluridone and ABA. Fluridone, by inhibiting ABA synthesis, may decrease the level of storage materials (Gamble and Mullet 1986). Fluridone activity depends on its concentration and plant species. The use of $10 \mu \mathrm{M}$ of fluridone to treat seeds of Hordeum vulgare resulted in the stimulation of growth, while the same fluridone concentration in Vicia faba cultures caused a very low rate of growth. In the present experiment, the posttreatment effect of fluridone on the maturation and conversion of tulip somatic embryos was seen in light conditions, where a significant reduction in percentage of deformed embryos, between ABA and fluridone treatment, and an increase in the development of shoots were observed. Fluridone applied together with ABA did not remove its inhibitory effect on tulip conversion. Gabryszewska (2000) also noted that fluridone increased the number of leaves in Peonia culture, but when used together 
with ABA, its action was thwarted. Opposite results were noted by Hooker and Thorpe (1998), in whose studies fluridone, applied in combination with exogenous abscisic acid, raised the inhibitory effect of ABA in Lycopersicon esculentum root culture. Fluridone, in concentration of $1-100 \mu \mathrm{M}$, did not have any beneficial effect on the conversion of Medicago sativa somatic embryos (Kępczyńska and Zielińska 2006). The above reports indicate that fluridone activity depends on plant species and kind of plant explants.

Somatic embryos as well as zygotic embryos synthesize and accumulate ABA (Hatzopoulos et al. 1990). There are no reports about endogenous ABA content during embryogenesis in tulips and other bulbous plants cultured in vitro. In the present study, control somatic embryos of tulip contained endogenous ABA, although its level was relatively low (1.82 $\left.\mathrm{nmol} \mathrm{g}^{-1} \mathrm{DW}\right)$ in comparison to the amount of ABA in the embryos, which were affected by exogenous ABA. The highest concentration of endogenous ABA (17.45 $\mathrm{nmol} \mathrm{g}^{-1}$ DW) was recorded after direct 1-week ABA treatment of torpedo embryos of tulip. Similar results have been obtained in somatic embryos of Hevea brasiliensis, while an addition of $10^{-5} \mathrm{M}$ of $\mathrm{ABA}$ increased its endogenous level from $10 \mathrm{nmol} / \mathrm{g} \mathrm{DW}$ (control) to above $150 \mathrm{nmol} / \mathrm{g}$ DW (Linossier et al. 1997). In our experiment, fluridone treatment of the tulip somatic embryos led to a nearly $50 \%$ decrease in ABA content. In existing reports, content of endogenous ABA depends on plant species and conditions of cultivation-supplementation with fluridone decreased ABA content (Hatzopoulos et al. 1990; Senger et al. 2001; Le Page-Degivry and Garello 1992).

In the present experiment, it was indicated that mature embryos, irrespective of $\mathrm{ABA} /$ fluridone treatment, contained similar level of endogenous ABA (0.59-1.33 nmol $\left.\mathrm{g}^{-1} \mathrm{DW}\right)$. It is highly probable that maturation of tulip somatic embryos is correlated with reduction of endogenous ABA content.

\section{Conclusion}

In conclusion, it must be emphasised that the present paper is so far the first report concerning ABA content in tulip somatic embryos during the process of embryo maturation. Our results indicate that ABA plays an important role during maturation of torpedo-shaped embryos and conversion of the mature somatic embryos. After ABA treatment, the tulip embryos cultivated in darkness distinguished lower embryo malformations in comparison with control. The endogenous ABA content in mature embryos, ten weeks after ABA treatment, remained at similar level in treated and non-treated embryos. That indicates that higher (than in control embryos) content of ABA is needed at torpedo stage to pass maturation process in a proper way.

Author contribution statement All authors contributed to this work. A.B. and M.M. designed, performed experiments, analytical measurements, and wrote the paper. F.J. performed analytical measurements.

Acknowledgements This study was financed by Polish Ministry of Science and Higher Education, within the project "The use of biotechnological methods in intensifying the production of selected ornamental plants" (DS No. 3500/KRO/2013).

Open Access This article is distributed under the terms of the Creative Commons Attribution 4.0 International License (http://crea tivecommons.org/licenses/by/4.0/), which permits unrestricted use, distribution, and reproduction in any medium, provided you give appropriate credit to the original author(s) and the source, provide a link to the Creative Commons license, and indicate if changes were made.

\section{References}

Ashihara H, Stasolla C, Loukanina N, Thorpe TA (2001) Purine metabolism during white spruce somatic embryo development: salvage of adenine, adenosine and inosine. Plant Sci 160:647-657

Attree SM, Moore D, Sawhney VK, Fowke LC (1991) Enhanced maturation and dessication tolerance of white spruce (Picea glauca (Moench) Voss) somatic embryos: effect of a nonplasmolysing water stress and abscisic acid. Ann Bot 68:519-525

Bach A, Pawłowska B (2006) Effect of light qualities on cultured in vitro ornamental bulbous plants. Floriculture, Ornamental and Plant Biotechnology. Advances and topical issues, vol II. Global Science Books, Ltd, UK, pp 271-276

Bach A, Ptak A (2001) Somatic embryogenesis and plant regeneration from ovaries of Tulipa gesneriana L. in in vitro cultures. Acta Hort 560:391-394

Bakhshaie M, Babalar M, Mirmasoumi M, Khalighi A (2010) Somatic embryogenesis and plant regeneration of Lilium ledebourii (Baker) Boiss., an endangered species. Plant Cell Tiss Org Cult 102:229-235

Bliss CI (1938) The Transformation of percentages for use in the analysis of variance. Ohio J Sci 38:9-12

Custers JBM, Ennik E, Eikelboom W, Dons JJM, van Lookeren Campagne MM (1997) Embryogenesis from isolated microspores of tulip: towards developing F1 hybrid varieties. Acta Hortic 430:259-266

De Hertogh A, Le Nard M (1993) The physiology of flower bulbs. Elsevier Science Publishers, The Netherlands, pp 612-682

Dodeman VL, Ducreux G, Kreis M (1997) Zygotic embryogenesis versus somatic embryogenesis. J Exp Bot 313:1493-1509

Eijk JP, Raamsdonk LWD, Eikelboom W, Bino RJ (1991) Interspecific crosses between Tulipa gesneriana cultivars and wild Tulipa species: a survey. Sex Plant Reprod 4:1-5

Find JI (1997) Changes in endogenous ABA levels in developing somatic embryos of Norway spruce (Picea abies (L.) Karst.) in relation to maturation medium, dessication and germination. Plant Sci 128:75-83

Gabryszewska E (2000) Effects of ABA, fluridone and light quality and dormancy of tissue-cultured Paeonia and Hosta shoots. Dev Biol Reg, 1st meeting, Germany. COST 843: 35-36 
Gamble PE, Mullet JE (1986) Inhibition of carotenoid accumulation and abscisic acid biosynthesis in fluridone-treated dark-grown barley. Eur J Biochem 160:117-121

Gao X, Yang D, Cao D, Ao M, Sui X, Wang Q, Kimatu JN, Wang L (2010) In vitro micropropagation of Freesia hybrida and the assessment of genetic and epigenetic stability in regenerated plantlets. J Plant Growth Regulat 29:257-267

Garcia R, Cidade D, Castellar A, Lips A, Magioli C, Callado C, Mansur E (2007) In vitro morphogenesis patterns from shoot apices of sugar cane are determined by light and type of growth regulator. Plant Cell Tiss Org Cult 90:181-190

Garcia-Martin G, Manzanera JA, Gonzales-Benito ME (2005) Effect of exogenous $\mathrm{ABA}$ on embryo maturation of endogenous level of ABA and IAA in Quercus suber somatic embryos. Plant Cell Tiss Org Cult 80:171-177

Goupil P, Loncle D, Druart N, Bellettre A, Rambour S (1998) Influence of $\mathrm{ABA}$ on nitrate reductase activity and carbohydrate metabolism in chicory roots (Cichorium intybus L.). J Exp Bot 49:1855-1862

Gude H, Dijkema MHGE (1997) Somatic embryogenesis in tulip. Acta Hort 430:275-280

Hatzopoulos P, Fong F, Renee Sung Z (1990) Abscisic acid regulation of DC8, a carrot embryonic gene. Plant Physiol 94:690-695

Hooker TS, Thorpe TA (1998) Effects of fluridone and abscisic acid on lateral root initiation and root elongation of excised tomato roots cultured in vitro. Plant Cell Tiss Org Cult 52:199-203

Kępczyńska E, Zielińska S (2006) Regulation of Medicago sativa L. somatic embryos regeneration by gibberellin A3 and abscisic acid in relation to starch content and $\alpha$-amylase activity. Plant Growth Regulat 49:209-217

Kraepiel Y, Miginiac E (1997) Photomorphogenesis and phytohormones. Plant Cell Environ 20:807-812

Le Page-Degivry MT, Garello G (1992) In situ abscisic acid synthesis. A requirement for induction of embryo dormancy in Helianthus annuus. Plant Physiol 98:1386-1390

Li B, Wolyn DJ (1996) Abscisic acid and ancymidol promote conversion of somatic embryos to plantlets and secondary embryogenesis in Asparagus officinalis L. In Vitro Cell Dev Biol Plant 32:223-226

Linossier L, Veisseire P, Cailloux F, Coudret A (1997) Effects of abscisic acid and high concentrations of PEG on Hevea brasiliensis somatic embryos development. Plant Sci 124:183-191

Madakadze RM, Senaratna T (2000) Effect of growth regulators on maturation on geranium (Pelargonium $\times$ hortorum) somatic embryos. Plant Growth Regulat 30:55-60

Malik M (2008) Comparison of different liquid/solid culture systems in the production of somatic embryos from Narcissus L. ovary explants. Plant Cell Tiss Org Cult 94:337-345

Maślanka M, Bach A (2005) Effect of abscisic acid on the morphology of tulip (Tulipa L.) somatic embryos. Abstracts. XII International Conference on Plant Embryology. 5-7 Sept 2005. Cracow, Poland. Acta Biol Cracov Ser Bot 47 Suppl 1: 73

Maślanka M, Bach A (2010) The effect of abscisic acid, ethylene and inhibitors of their biosynthesis (fluridone and salicylic acid) on somatic embryos conversion in tulips. Ecol Chem Eng 17:1135-1139

Mauri PV, Manzanera JA (2004) Effect of abscisic acid and stratification on somatic embryo maturation and germination of Holm Oak (Quercus ilex L.). In Vitro Cell Dev Biol Plant 40:495-498

Minocha R, Smith DR, Reeves C, Steele KD, Minocha CS (1999) Polyamine levels during the development of zygotic and somatic embryos of Pinus radiata. Physiol Plant 105:155-164

Murashige T, Skoog F (1962) A revised medium for rapid growth and bioassays with tobacco tissue culture. Physiol Plant 15:473-497
Nhut DT, Hanh NTM, Tuan PQ, Nguyet LTM, Tram NTH, Chinh NC, Nguen NH, Vinh DN (2006) Liquid culture as a positive condition to induce and enhance quality and quantity of somatic embryogenesis of Lilium longiflorum. Sci Hort 110:93-97

Nolan KE, Rose RJ (1998) Plant regeneration from cultured Medicago truncatula with particular reference to abscisic acid and light treatments. Aust J Bot 46:151-160

Ogata Y, Iizuka M, Nakayama D, Ikeda M, Kamada H, Koshiba T (2005) Possible involvement of abscisic acid in the induction of secondary somatic embryogenesis on seed-coat-derived carrot somatic embryos. Planta 221:417-423

Perera PIP, Vidhanaarachchi VRM, Gunathilake TR, Yakandawala DMD, Hocher V, Verdeil JL, Weerakoon LK (2009) Effect of plant growth regulators on ovary culture of coconut (Cocos nucifera L.). Plant Cell Tiss Org Cult 1:73-81

Ptak A, Bach A (2007) Somatic embryogenesis in tulip (Tulipa gesneriana L.) flower stem cultures. In Vitro Cell Dev Biol Plant 43:35-39

Quiroz-Figueroa FR, Rojas-Herrera R, Galaz-Avalos RM, LoyolaVargas VM (2006) Embryo production through somatic embryogenesis can be used to study cell differentiation in plants. Plant Cell Tiss Org Cult 86:285-301

Raghavan V (1997) Molecular embryology of flowering plants. Somatic embryogenesis. Cambridge University Press, Cambridge, pp 467-499

Rees AR (1992) Propagation ornamental bulbs, corms and tubers. CAB, Wallingford, pp 93-111

Reynolds TL, Crawford RL (1997) Effects of light on the accumulation of abscisic acid and expression of an early cysteinelabeled metallothionein gene in microspores of Triticum aestivum during induced embryogenic development. Plant Cell Rep $16: 458-463$

Schmidt MA, Tucker DM, Cahoon EB, Parrot WA (2005) Towards normalization of soybean somatic embryo maturation. Plant Cell Rep 24:383-391

Senger S, Mock HP, Conrad U, Manteuffel R (2001) Immunomodulation of ABA function affects early events in somatic embryo development. Plant Cell Rep 20:112-120

Seo M, Koshiba T (2002) Complex regulation of ABA biosynthesis in plants. Trends Plant Sci 1:41-48

Sreedhar L, Bewley JD (1998) Nitrogen- and sulphur-containing compounds enhance the synthesis of storage reserves in developing somatic embryos of alfalfa (Medicago sativa L.). Plant Sci 134:31-44

Stasolla C, Yeung EC (2003) Recent advances in conifer somatic embryogenesis: improving somatic embryo quality. Plant Cell Tiss Org Cult 74:15-35

Stefaniak B (1994) Somatic embryogenesis and plant regeneration of Gladiolus (Gladiolus hort.). Plant Cell Rep 13:386-389

Subotić A, Trifunović M, Jevremović S, Petrić M (2010) Morphohistological study of direct somatic embryogenesis in endangered species Frittilaria meleagris. Biol Plant 3:592-596

Tettero FAA, Hoekstra FA, Karssen CM (1995) Induction of complete dessication tolerance in carrot (Daucus carota) embryoids. J Plant Physiol 145:349-356

Vágner M, Vondrákova Z, Strnadová Z, Adner J, Macháćkova I (1998) Endogenous levels of plant growth hormones during early stages of somatic embryogenesis of Picea abies. Adv Hort Sci 12:11-18

Walker-Simmons MK, Abrams SR (1991) Use of ABA immunoassays. In: Davies WJ, Jones HG (eds) Abscisic acid, physiology and biochemistry. Bios Scientific Publishers, Oxford, pp 53-63

Weatherwax SC, Ong MS, Degenhardt J, Bray EA, Tobin EM (1996) The interaction of light and abscisic acid in the regulation of plant gene expression. Plant Physiol 2:363-370 
Yoshioka T, Endo T, Satoh S (1998) Restoration of seed germination at supraoptimal temperatures by fluridone, an inhibitor of abscisic acid biosynthesis. Plant Cell Physiol 39:307-312

Zimmerman JL (1993) Somatic embryogenesis: a model for early development in higher plants. Plant Cell 5:1411-1423
Ziv M (2005) Simple bioreactors for mass propagation of plants. In: Hvoslef-Eide AK, Preil W (eds) Liquid culture systems for in vitro plant propagation. Springer, Berlin, pp 79-93 